\title{
Successful treatment of secondary poor graft function post allogeneic hematopoietic stem cell transplantation with eltrombopag
}

\author{
Cen Tang ${ }^{1,2,3+}$, Feng Chen ${ }^{1,2,3+}$, Danqing Kong ${ }^{1,2,3}$, Qinfen Ma ${ }^{1,2,3}$, Haiping Dai ${ }^{1,2,3}$, Jia Yin ${ }^{1,2,3}$, Zheng $\mathrm{Li}^{1,2,3}$, \\ Jia Chen ${ }^{1,2,3}$, Xiaming Zhu $u^{1,2,3}$, Xinliang Mao ${ }^{4,5^{*}}$, Depei $\mathrm{Wu}^{1,2,3^{*}}$ and Xiaowen Tang ${ }^{1,2,3^{*}}$
}

\begin{abstract}
Poor graft function (PGF) is a life-threatening complication after allogeneic hematopoietic stem cell transplantation (allo-HSCT). Current treatment strategies include the use of growth factors, CD34 $4^{+}$-selected stem cell boost, mesenchymal stem cell transfusion, and second allo-HSCT, but these treatments are not effective in all patients. Eltrombopag, an oral thrombopoietin receptor agonist, which showed promising results in severe aplasia anemia, may be an alternative choice for PGF patients. Therefore, we treated 12 patients who responded poorly to standard treatments for secondary PGF after allo-HSCT with eltrombopag. The median duration was 116 (35-1000) days from transplantation to PGF diagnosis and 59 (30-180) days from PGF diagnosis to eltrombopag treatment. Eltrombopag was started at a dose of $25 \mathrm{mg} / \mathrm{d}$ for 3 days and then increased to 50 or $75 \mathrm{mg} / \mathrm{d}$. Median treatment duration was 8 (2-23) weeks. Ten patients (83.3\%) responded to the treatment: 8 achieved complete response (CR), and the remaining 2 achieved partial response. In the 10 responding subjects, median platelet count was $18(5-27) \times 10^{9} / \mathrm{L}$ vs $74(30-117) \times 10^{9} / \mathrm{L}$ prior to and after treatment. Neutrophil count was $0.51(0.28-0.69) \times 10^{9} / \mathrm{L}$ vs $1.84(0.78-4.90)$ $\times 10^{9} / \mathrm{L}$. Hemoglobin was $88(63-123)$ vs $101(78-134) \mathrm{g} / \mathrm{L}$. In the 8 patients who achieved CR, the time from eltrombopag initiation to achieving CR was 29 (10-49) days; the response lasted until the last follow-up in all 8 CR subjects (10-18 months). The 12-month overall survival rate was $83.3 \%$. There was no treatment-related mortality and no evidence of cataract, thrombosis, or any other grade 3/4 toxicities.
\end{abstract}

Keywords: Eltrombopag, Secondary poor graft function, Allogeneic hematopoietic stem cell transplantation

Poor graft function (PGF) is a life-threatening complication that occurs in $5-27 \%$ of the patients following allogeneic hematopoietic stem cell transplantation (allo-HSCT) [1, 2]. Management strategies, including the use of growth factors [3], CD34 ${ }^{+}$-selected stem cell boost [4], mesenchymal stem cell (MSC) transfusion [5], and second allo-HSCT [6], are not effective for all patients.

\footnotetext{
*Correspondence: xinliangmao@suda.edu.cn; drwudepei@163.com; xwtang1020@163.com

${ }^{\dagger}$ Cen Tang and Feng Chen contributed equally to this work.

${ }^{4}$ Department of Pharmacology, College of Pharmaceutical Sciences, Soochow University, Suzhou, Jiangsu, China

'Department of Hematology, The First Affiliated Hospital of Soochow

University, Jiangsu Institute of Hematology, Suzhou, China

Full list of author information is available at the end of the article
}

Eltrombopag, a c-mpl receptor agonist, is an effective treatment for immune thrombocytopenic purpura (ITP) and thrombocytopenia after transplantation $[7,8]$. In a recent phase I/II study of 92 patients with severe aplastic anemia (SAA) [9], eltrombopag plus standard immunosuppression resulted in 94\% hematological response rate. Considering the similarity between PGF and SAA, we speculated that eltrombopag is also effective against PGF. This retrospective analysis included 12 consecutive patients receiving eltrombopag for secondary PGF after allo-HSCT during a period from February 2016 to October 2017. Secondary PGF (sPGF) was defined as: cytopenia in at least two lineages (platelet $<20 \times 10^{9} / \mathrm{L}$, neutrophil $<0.5 \times 10^{9} / \mathrm{L}$, hemoglobin $<70 \mathrm{~g} / \mathrm{L}$ ), and/or with transfusion requirements beyond day +28 , with full donor

(c) The Author(s). 2018 Open Access This article is distributed under the terms of the Creative Commons Attribution 4.0 International License (http://creativecommons.org/licenses/by/4.0/), which permits unrestricted use, distribution, and 
chimerism, without relapse or severe graft versus host disease, and lasting at least for 14 consecutive days $[5,10]$.

Clinical characteristics of the subjects were summarized in Table 1 . All 12 patients responded poorly to previous treatments, including growth factors $(n=12)$, MSCs $(n=$ $2)$, and decitabine $(n=2)$. All but one patient were transfusion-dependent. The median duration was 116 (35-1000) days from transplantation to sPGF diagnosis and 59 (30-180) days from sPGF diagnosis to eltrombopag treatment. Eltrombopag was started at a dose of $25 \mathrm{mg} / \mathrm{d}$ for 3 days and then increased to 50 or $75 \mathrm{mg} / \mathrm{d}$. Median duration of eltrombopag treatment was 8 (2-23) weeks. Total dosage was $2487.5(700-10,500) \mathrm{mg}$.

The overall response rate (ORR) was $83.3 \%$ (10/12). Eight patients achieved complete response (CR), as defined by platelet $\geq 50 \times 10^{9} / \mathrm{L}$, neutrophil $\geq 1.0 \times 10^{9} / \mathrm{L}$, and hemoglobin $\geq 90 \mathrm{~g} / \mathrm{L}$, without blood cell transfusion or granulocyte colony stimulating factor for $\geq 7$ consecutive days [5]; the time from eltrombopag initiation to achieving CR was 29 (10-49) days. Two patients achieved partial response, as defined by hematopoietic engraftment of at least two lineages (platelet $\geq 20 \times 10^{9} / \mathrm{L}$, neutrophil $\geq 0.5 \times 10^{9} / \mathrm{L}$ and hemoglobin $\geq 70 \mathrm{~g} / \mathrm{L}$ ) but not fulfilling CR criteria.
The follow-up was 18.5 (3-37) months post transplantation. Among the 10 responding patients, median platelet count was $18(5-27) \times 10^{9} / \mathrm{L}$ vs $74(30-117) \times 10^{9} / \mathrm{L}$ prior to and after treatment $(P=0.00008$; Fig. 1a). Median neutrophil count was $0.51(0.28-0.69) \times 10^{9} / \mathrm{L}$ vs $1.84(0.78-$ $4.90) \times 10^{9} / \mathrm{L} \quad(P=0.0015$; Fig. 1b). Median hemoglobin was $88(63-123)$ vs 101 (78-134) g/L ( $P=0.0001$; Fig. 1c). The response lasted to the last follow-up (10-18 months) in all 8 subjects who achieved CR.

Eltrombopag was well tolerated by all 12 patients. There were no treatment-related mortality and no evidence of cataract, thrombosis, or any other grade $3 / 4$ toxicities. Upon the last follow-up, 9 subjects were PGF-free; 9 had normal blood cell counts. The 12-month overall survival rate after transplantation was $83.3 \%$ (95\% CI: 62-100\%).

With increasing application of alternative donor in transplantation, especially haploidentical HSCT and cord blood transplantation, PGF has become a major obstacle contributing to higher non-relapse mortality. Eltrombopag, as a stimulator of platelet production, promotes the proliferation of megakaryocytes by binding with thrombopoietin receptor (c-mpl) [7], also can promote hematopoiesis along all three lineages. Indeed, clinical trials have establishedefficacy of eltrombopag against ITP, thrombocytopenia after

Table 1 Clinical Characteristics of the 12 sPGF patients

\begin{tabular}{|c|c|c|c|c|c|c|c|c|c|c|}
\hline No. & Age & Sex & $\begin{array}{l}\text { Underlying } \\
\text { disease }\end{array}$ & Cytopenia & Failed previous treatments (duration) & $\begin{array}{l}\text { Eltrom } \\
\text { duration, } \\
\text { weeks }\end{array}$ & $\begin{array}{l}\text { Total dose of } \\
\text { eltrom, mg }\end{array}$ & $\begin{array}{l}\text { Time to } \\
\mathrm{CR} \text {, days }\end{array}$ & $\begin{array}{l}\text { Best } \\
\text { response }\end{array}$ & $\begin{array}{l}\text { Last } \\
\text { follow-up }\end{array}$ \\
\hline 1 & 21 & M & ALL & $\mathrm{N}, \mathrm{PLT}$ & $\begin{array}{l}\text { G-CSF, EPO, TPO, IL-11 PLT transfusion- } \\
\text { dependent for } 12 \text { months, MSC infusion } \\
\text { for } 4 \text { times }\end{array}$ & 13 & 6475 & 43 & $C R$ & Alive \\
\hline 2 & 25 & $\mathrm{~F}$ & ALL & $\mathrm{N}, \mathrm{HB}, \mathrm{PLT}$ & $\begin{array}{l}\text { G-CSF, EPO, TPO, PLT transfusion-dependent } \\
\text { for } 2 \text { months }\end{array}$ & 2 & 700 & 10 & $C R$ & Alive \\
\hline 3 & 35 & $\mathrm{~F}$ & ALL & $\mathrm{N}, \mathrm{HB}, \mathrm{PLT}$ & $\begin{array}{l}\text { G-CSF, EPO, TPO, RBC and PLT transfusion- } \\
\text { dependent for } 2 \text { months }\end{array}$ & 2 & 700 & NA & PR & Dead \\
\hline 4 & 22 & M & ALL & $\mathrm{N}, \mathrm{HB}, \mathrm{PLT}$ & $\begin{array}{l}\text { G-CSF, PLT transfusion-dependent for } \\
1 \text { month }\end{array}$ & 8 & 4200 & NA & NR & Dead \\
\hline 5 & 52 & M & AML & $\mathrm{N}, \mathrm{PLT}$ & $\begin{array}{l}\text { G-CSF, IL-11, PLT transfusion-dependent } \\
\text { for } 1 \text { month }\end{array}$ & 4 & 700 & 36 & $C R$ & Alive \\
\hline 6 & 27 & $\mathrm{~F}$ & AML & $\mathrm{N}, \mathrm{HB}, \mathrm{PLT}$ & $\begin{array}{l}\text { G-CSF, EPO, TPO, RBC and PLT transfusion- } \\
\text { dependent for } 3 \text { months }\end{array}$ & 7 & 1725 & NA & PR & Dead \\
\hline 7 & 53 & M & AML & $\mathrm{N}, \mathrm{PLT}$ & $\begin{array}{l}\text { G-CSF, EPO, TPO, PLT transfusion-dependent } \\
\text { for } 1 \text { month }\end{array}$ & 6 & 2175 & 25 & $C R$ & Alive \\
\hline 8 & 42 & M & MPAL & $\mathrm{N}, \mathrm{HB}, \mathrm{PLT}$ & $\begin{array}{l}\text { G-CSF, EPO, TPO, RBC and PLT transfusion- } \\
\text { dependent for } 3 \text { months; DAC for } 1 \text { course }\end{array}$ & 4 & 1400 & NA & NR & Alive \\
\hline 9 & 42 & $\mathrm{~F}$ & SAA & $\mathrm{N}, \mathrm{HB}, \mathrm{PLT}$ & $\begin{array}{l}\text { G-CSF, PLT transfusion-dependent for } 1 \\
\text { month; DAC for } 1 \text { course }\end{array}$ & 8 & 4200 & 30 & $C R$ & Alive \\
\hline 10 & 29 & $\mathrm{~F}$ & SAA & $\mathrm{N}, \mathrm{PLT}$ & G-CSF, TPO-dependent for 1 month & 23 & 10,500 & 28 & $C R$ & Alive \\
\hline 11 & 33 & M & SAA & $\mathrm{N}, \mathrm{PLT}$ & $\begin{array}{l}\text { G-CSF, EPO, TPO, PLT transfusion-dependent } \\
\text { for } 2 \text { months, MSC infusion for } 3 \text { times }\end{array}$ & 8 & 4025 & 49 & $C R$ & Alive \\
\hline 12 & 47 & M & MF & $\mathrm{N}, \mathrm{PLT}$ & G-CSF, PLT transfusion-dependent for 1 month & 8 & 2800 & 20 & $C R$ & Alive \\
\hline
\end{tabular}

$M$ male, $F$ female, $N$ neutrophil, $H B$ hemoglobin, $P L T$ platelet, $s P G F$ secondary poor graft function, $A M L$ acute myeloid leukemia, $A L L$ acute lymphocytic leukemia, MPAL mixed phenotype acute leukemia, $S A A$ severe aplasia anemia, $M F$ myelofibrosis, $C R$ complete response, $P R$ partial response, $N R$ no response, $G$-CSF granulocyte colony-stimulating factor, EPO erythropoietin, TPO thrombopoietin, MSC mesenchymal stem cell, DAC decitabine, NA not available 

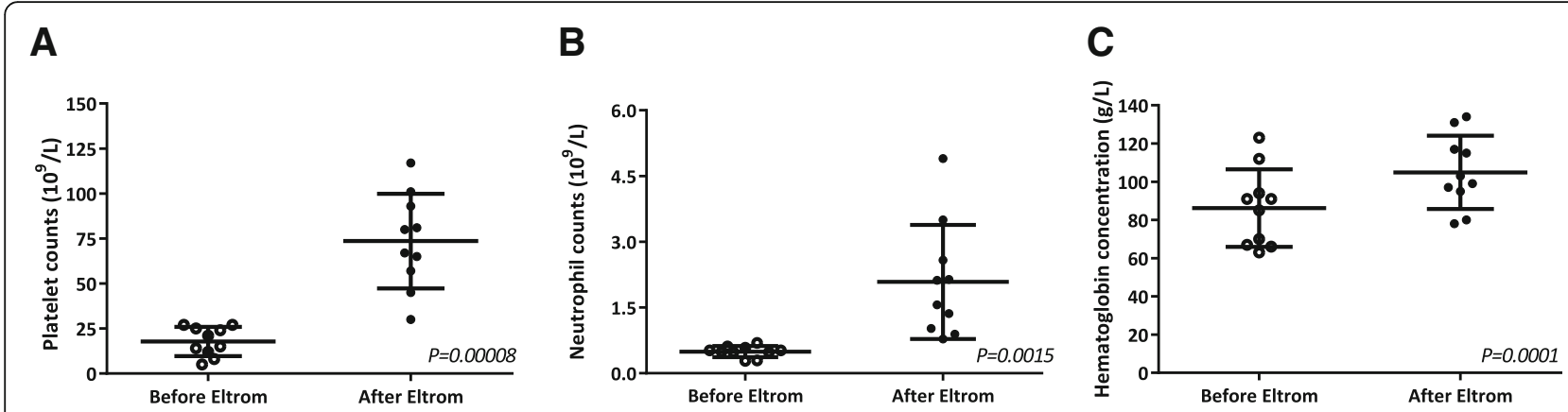

Fig. 1 Blood cell counts prior to and after eltrombopag treatment. The analysis included only 10 responding patients. a Median platelet count was $18(5-27) \times 10^{9} / \mathrm{L}$ vs $74(30-117) \times 10^{9} / \mathrm{L}$ before and after the treatment $(P=0.00008)$. b Median neutrophil count was $0.51(0.28-0.69) \times 10^{9} / \mathrm{L}$ vs $1.84(0.78-4.90) \times 10^{9} / \mathrm{L}(P=0.0015)$. c Median hemoglobin level was $88(63-123)$ vs $101(78-134) \mathrm{g} / \mathrm{L}(P=0.0001)$

transplantation, as well as SAA [7-9]. Considering the fact that all patients in the current study failed previous treatments for SPGF, the ORR (83.3\%) and CR (66.7\%) are encouraging. Another important finding is the relatively long duration of the response after eltrombopag withdrawal. The current study represents the first case series of using eltrombopag for secondary PGF after allo-HSCT. Due to the retrospective nature of the study and the small sample size, the results must be considered preliminary and should be verified by randomized controlled trials in the future.

In summary, we showed that eltrombopag could produce a rapid and sustaining response in patients with sPGF after allo-HSCT who failed treatment with conventional treatments. This finding is particularly interesting considering the increasing use of alternative donor HSCT and high rate of non-relapse mortality due to PGF.

\section{Abbreviations \\ allo-HSCT: Allogeneic hematopoietic stem cell transplantation; CR: Complete response; ITP: Immune thrombocytopenic purpura; MSC: Mesenchymal stem cell; ORR: Overall response rate; PGF: Poor graft function; SAA: Severe aplastic anemia; sPGF: Secondary PGF}

\section{Funding}

This work was supported, in part by research grants from the National Key R\&D Program of China (2016YFC0902800), National Natural Science Foundation of China (81270645, 81770154, 8187010379), Priority Academic Program Development of Jiangsu Higher Education Institutions (PAPD), Frontier Clinical Technical Project of the Science and Technology Department of Jiangsu Province (BE2017655), and the Jiangsu Provincial Medical Talent (ZDRCA2016045)

\section{Availability of data and materials}

All data generated or analyzed during this study are included in this published article and its supplementary information files.

\section{Authors' contributions}

$X T$ and DW designed the study. CT, FC, DK, QM, HD, ZL, JY, JC, and XZ participated in the collection and analysis the data. $C T$ and $F C$ wrote the manuscript. XM and XT were responsible of the critical review and revision of this manuscript. All authors provided the approval of the final manuscript for submission.

\section{Ethics approval and consent to participate}

This study was approved by the Ethics Committee of the First Affiliated Hospital of Soochow University.
Consent for publication

Not applicable.

\section{Competing interests}

The authors declare that they have no competing interests.

\section{Publisher's Note}

Springer Nature remains neutral with regard to jurisdictional claims in published maps and institutional affiliations.

\section{Author details}

'Department of Hematology, The First Affiliated Hospital of Soochow University, Jiangsu Institute of Hematology, Suzhou, China. Institute of Blood and Marrow Transplantation, Suzhou, China. ${ }^{3}$ Collaborative Innovation Center of Hematology, Soochow University, Suzhou, China. ${ }^{4}$ Department of Pharmacology, College of Pharmaceutical Sciences, Soochow University, Suzhou, Jiangsu, China. ${ }^{5}$ Institute of Clinical Pharmacology, Guangzhou University of Chinese Medicine, 12 Jichang Road, Baiyun District, Guangzhou 510405, China.

Received: 26 May 2018 Accepted: 8 August 2018

Published online: 16 August 2018

\section{References}

1. Lee $\mathrm{KH}$, Lee JH, Choi SJ, Lee JH, Kim S, Seol M, et al. Failure of trilineage blood cell reconstitution after initial neutrophil engraftment in patients undergoing allogeneic hematopoietic cell transplantation - frequency and outcomes. Bone Marrow Transplant. 2004;33(7):729-34.

2. Woolfrey A, Anasetti C. Allogeneic hematopoietic stem-cell engraftment and graft failure. Pediatr Transplant. 1999;3(Suppl 1):35-40.

3. Bittencourt H, Rocha V, Filion A, lonescu I, Herr AL, Garnier F, et al. Granulocyte colony-stimulating factor for poor graft function afte allogeneic stem cell transplantation: 3 days of G-CSF identifies long-term responders. Bone Marrow Transplant. 2005;36(5):431-5.

4. Ghobadi A, Fiala MA, Ramsingh G, Gao F, Abboud CN, StockerlGoldstein K, et al. Fresh or cryopreserved CD34(+)-selected mobilized peripheral blood stem and progenitor cells for the treatment of poor graft function after allogeneic hematopoietic cell transplantation. Biol Blood Marrow Transplant. 2017;23(7):1072-7.

5. Liu X, Wu M, Peng Y, Chen X, Sun J, Huang F, et al. Improvement in poor graft function after allogeneic hematopoietic stem cell transplantation upon administration of mesenchymal stem cells from third-party donors: a pilot prospective study. Cell Transplant. 2014;23(9):1087-98.

6. Guardiola P, Kuentz M, Garban F, Blaise D, Reiffers J, Attal M, et al. Second early allogeneic stem cell transplantations for graft failure in acute leukaemia, chronic myeloid leukaemia and aplastic anaemia. French Society of Bone Marrow Transplantation. Br J Haematol. 2000;111(1):292-302.

7. Wong RSM, Saleh MN, Khelif A, Salama A, Portella MSO, Burgess P, et al. Safety and efficacy of long-term treatment of chronic/persistent ITP with eltrombopag: final results of the EXTEND study. Blood. 2017;130(23):2527-36. 
8. Tanaka T, Inamoto Y, Yamashita T, Fuji S, Okinaka K, Kurosawa S, et al. Eltrombopag for treatment of thrombocytopenia after allogeneic hematopoietic cell transplantation. Biol Blood Marrow Transplant. 2016;22(5): 919-24.

9. Townsley DM, Scheinberg P, Winkler T, Desmond R, Dumitriu B, Rios O, et al. Eltrombopag added to standard immunosuppression for aplastic anemia. N Engl J Med. 2017;376(16):1540-50

10. Kong Y, Chang YJ, Wang YZ, Chen YH, Han W, Wang Y, et al. Association of an impaired bone marrow microenvironment with secondary poor graft function after allogeneic hematopoietic stem cell transplantation. Biol Blood Marrow Transplant. 2013;19(10):1465-73.

Ready to submit your research? Choose BMC and benefit from:

- fast, convenient online submission

- thorough peer review by experienced researchers in your field

- rapid publication on acceptance

- support for research data, including large and complex data types

- gold Open Access which fosters wider collaboration and increased citations

- maximum visibility for your research: over $100 \mathrm{M}$ website views per year

At BMC, research is always in progress.

Learn more biomedcentral.com/submissions 